\title{
Globalization and Asian Pentecostalism in the Twenty-First Century
}

\author{
Connie Au \\ Chinese Christian Literature Council, Hong Kong, Hong Kong
}

\begin{abstract}
This article aims to explore the development of Pentecostalism in Asia under the tide of globalization since the beginning of the twenty-first century. It will do so in three sections. First, it investigates megachurches and the prosperity gospel in Asian countries and regions that enjoy a greater extent of liberty and where neo-capitalism has emerged. Second, the article discusses the situation of Pentecostalism in countries ruled by totalitarian regimes. Pentecostalism cannot grow freely there, but it is relatively safe for Pentecostals to provide humanitarian relief and social services. Third, the article illustrates how migration as a major phenomenon of globalization has influenced pentecostal mission. It focuses on African Pentecostals who engage in trades in China and the Filipino/a Charismatics who are migrant workers. In the conclusion, the article discusses how the coronavirus pandemic has been reshaping globalization and Pentecostalism and offers a possible way to see the future.
\end{abstract}

\section{Keywords}

globalization - neo-capitalism - megachurches - prosperity gospel - migration mission - coronavirus 
Globalization has shaped the values, lifestyle, policies, economies, religions, ecologies, communications, and networking around the world since the end of the Cold War in the early 199os. It is one of the demonstrations of neoliberal capitalism characterized by the "trans nationalisation of production, the 'expanding scale and abstraction [and acceleration] of transactions across the globe, the tension between the mobility of capital and the fixities of the nation state, the erosion of many of the institutional forms of liberal democratic society,' a culture of consumerism, and so on."2 Besides the immediate perception of the pursuit for the maximization of wealth through global financial and investment markets, globalization also encourages the prospect of people around the world sharing information and ideas through the internet and studying in foreign countries; they can increase wealth and defeat poverty through world trade; and they can exchange life and cultural experiences through tourism by means of faster and cheaper travel by air and sea.

To realize this tremendous plan in human history, some wealthy countries have been investing in certain developing countries in Africa, Latin America, and Asia. These countries provide low-cost labor, vast lands, and natural resources without many legal restrictions on environmental and labor rights. Asia has been the continent attracting global investments through visible means such as factories, and invisible ones such as financial products in stock and currency markets. This continent is the place where both religious fundamentalism (Afghanistan, Iran, and Pakistan) and communism (China, Cambodia, North Korea, Laos, and Vietnam) have taken root. These countries tend to produce closed societies, and the regimes are paranoid about foreign infiltration and free transmission of information through foreign investments and NGOS. However, as the pressure of poverty and social instability accumulate, these regimes have been forced to open up their markets gradually to join the tide of globalization.

Pentecostalism in Asia is a display of how Pentecostalism leverages globalization to realize significant geographical and numerical growth. Protestant megachurches and Catholic Charismatic groups in the Philippines have attracted scholarly studies in the disciplines of sociology, theology, religious

1 "Pentecostalism" is used to refer to Classical Pentecostals and Protestant and Catholic Charismatics throughout the article, all of whom share the belief in the experiences of the Holy Spirit.

2 Benjamin Kirby, "Pentecostalism, Economics, Capitalism: Putting the Protestant Ethic to Work," Religion 49, no. 4 (2019): 14. 
studies, psychology and so on. Although the number of Pentecostals in the Three-Self and house churches in China is unknown, it is believed that Pentecostalism has widely spread there.

\section{Overview}

This article aims to explore the development of Pentecostalism in Asia under the tide of globalization since the beginning of the twenty-first century. It discusses the situation primarily from a social scientific approach assisted by the historical background of certain countries. First, this article investigates the growth of Pentecostalism in relatively free countries and regions in which, to a larger extent, democracy, liberty, and free economies are implemented, including Singapore, Malaysia, India, Hong Kong, Taiwan, the Philippines, and South Korea. Pentecostalism can grow as much as it can without much political oppression. Also, in these regions that tend to be wealthier and have a longer history of practicing capitalism, the prosperity gospel is stressed, and megachurches can easily be established. One exceptional case is Japan, one of the seven largest economies in the world, which is qualified as a member of the G7. ${ }^{3}$ Japan also embraces religious freedom and democracy, but Pentecostalism is rather small, as is Christianity as a whole. Since illustrating the growth of Pentecostalism in individual countries will take too much space, I focus on their common denominators - the prosperity gospel and megachurches- to discuss the growth of Pentecostalism.

Second, I explore the situation of Pentecostalism in less free countries ruled by totalitarian regimes. These countries shut down their markets and societies from the outside world for decades but reopened them in the last twenty to forty years. This includes Cambodia, Myanmar, Vietnam, and China. I provide the historical background of their political regimes and how they reopened themselves for foreign investors to develop their economies, and for humanitarian NGO s and churches to provide social and medical services. Pentecostalism cannot grow freely there due to political oppression, but it is relatively safe for Pentecostals to provide social services. Although the prosperity gospel might be taught and megachurches developed in China, since there is no guarantee of religious freedom, Pentecostals, especially those in the house churches, bear the risk of persecution at any time. Although globalization may have been knocking on the doors of countries like North Korea and Iran for

3 The other six are US, UK, Canada, France, Italy, and Germany. 
years, they remain tightly closed, so it is impossible to know the situation of Pentecostalism in these countries. The article does not cover Central Asia and the Middle East due to lack of information on the recent development of Pentecostalism in these regions.

Third, this article illustrates a typical phenomenon of globalization - migration, which is also the main reason for the globalization of Pentecostalism in the twenty-first century. World Migration Report 2020 predicts that there will be 164 million migrant workers in 2020. ${ }^{4}$ Asia hosted 84 million migrants in 2019 and Europe came second with 80 million. Between 2000 and 2019, Asia underwent the most significant growth of migrants at 69 percent (about 34 million people). ${ }^{5}$ Hence, it is worth addressing the situation of migration in Asia and how pentecostal migrants engage in mission work as they work in a foreign country. I will particularly focus on the African Pentecostals who come to China for trading opportunities and Filipina Catholic Charismatics who work as domestic helpers and nurses around the world.

In the conclusion, I will briefly discuss how the coronavirus has changed the faces of globalization and pentecostal spirituality and a possible way to see the future.

\section{Pentecostalism in Freer Asian Countries}

\subsection{Prosperity Gospel and Megachurches}

The prosperity gospel originated in the US and advocates a message of wealth and health endowed by God. It stretches the meaning of salvation in Christianity from its spiritual dimension, namely, eternal life after death, to hereand-now material and physical provision. In Asia, the prosperity gospel was probably first taught by Yonggi Cho under the title of "Theology of Blessings." He witnessed his own country being afflicted with widespread impoverishment after Japanese colonialism and the Korean War in the late 1950s. Through his prayer and teaching, those who desperately suffered from hunger, illnesses, and pain miraculously experienced healing and the provision of basic material needs. ${ }^{6}$ This teaching implants a belief that anyone who is faithful to God can move from "victim to victor."

4 International Organization for Migration, World Migration Report 2020 (Geneva: International Organization for Migration, 2019), 10.

5 International Organization for Migration, World Migration Report 2020, 24.

6 Wonsuk Ma, "David Yonggi Cho's Theology of Blessing: Basis, Legitimacy and Limitations," Evangelical Review of Theology 35, no. 2 (2011): 146. 
In the 1970s and 1980s, South Korea was one of the four "Asian dragons" and has developed to be a modern country and technological pioneer. The interpretation of the prosperity gospel is not so much about solving poverty as about gaining more by giving more. This does not only apply to South Korea, but also to other Asian countries such as Singapore, Indonesia, Malaysia, and India, which have opened up their markets for foreign investments and engaged in world trade since the 1970s. Their rapid modernization, urbanization, and industrialization fueled by capitalism not only increased the wealth of their societies but also attracted people to move from rural to urban areas. Subsequently, the middle class increased and indirectly influenced the establishment of megachurches. ${ }^{7}$ As Kong Hee, senior pastor of the City Harvest Church in Singapore, declared to his congregation in 2012, "Prosperity shouldn't be foreign to us Singaporeans" and "prosperity is enshrined in the Singapore psyche." Therefore, "to achieve happiness, prosperity and progress for our nation" was "consistent with our Christian values." In the cases of Indonesia and Malaysia, the establishment of megachurches is not only associated with the economic progress but also involves the ethnic Chinese minorities who cling to Christianity to build up their religious identity in the multireligious societies. Terence Chong ascribes the growth of Indonesian megachurches as "a result of identity politics, economic growth and cultural network."9

Membership sizes of megachurches range from ten thousand to two million. In South Korea, Yoido Full Gospel Church reached a membership of one million in the 1970s. In Indonesia, Gereja Bethel Indonesia has developed 5,200 congregations with over two million members. ${ }^{10} \mathrm{JKI}$ Injil Kerajaan (The Gospel of the Kingdom Church/GKC) founded by Petrus Agung Purnomo (1962-2016) in Semarang, Central Java, had approximately 16 ,ooo weekly attendants. ${ }^{11}$ Chong humorously adopts the term "Big Four," commonly used to refer to the four

7 Terence Chong, "Megachurches in Singapore: The Faith of an Emergent Middle Class," Pacific Affairs 88, no. 2 (June 2015): 222.

8 Terence Chong, "Of Riches and Faith: The Prosperity Gospels of Megachurches in Singapore," in Juliette Koning and Gwenaël Njoto-Feillard, eds., New Religiosities, Modern Capitalism, and Moral Complexities in Southeast Asia (London: Palgrave MacMillan, 2017), 162.

9 Chong, "Megachurches in Singapore," 223.

10 Terence Chong and Daniel P.S. Goh, "Asian Pentecostalism: Revivals, Mega-churches, and Social Engagement," in Bryan S. Turner and Oscar Salemink, eds., Routledge Handbook of Religions in Asia (London: Routledge, 2014), 409.

11 Rony Chandra Kristanto, "Purnomo, Petrus Agung," in Michael Wilkinson et al., eds., Brill's Encyclopedia of Global Pentecostalism Online (Leiden: Brill, forthcoming). 
largest accounting firms in the world, ${ }^{12}$ to name the four biggest churches in Singapore: City Harvest Church (about 33,00o members), New Creation Church (about 24,000 members), Lighthouse Evangelism (about 12,00o members), and Faith Community Baptist Church (about 10,0oo members).${ }^{13}$ Bread of Life Christian Church (BLCC) in Taipei is attended by an average of 10,000 every Sunday. Jesus is Lord Church in the Philippines is probably one of the largest pentecostal churches in Asia.

There are some smaller megachurches of 6,00o to 9,00o in Hong Kong that have American Classical Pentecostal roots, such as Wing Kwong Holiness Pentecostal Church and Yuen Long Kam Kwong Church (Assemblies of God), as well as 611 Bread of Life Christian Church, which is a branch of the BLCC. In Thailand, a Buddhist country in which Protestants only make up 0.7 percent of the population, an independent charismatic church Hope of Bangkok, founded by Kriengsak Charoenwongsak and his wife in 1981, had an average attendance of 2,000 in three services every Sunday by $2018 . .^{14}$

Nevertheless, the growth of Pentecostalism in some of these countries is restricted by religious laws. For example, the Maintenance of Religious Harmony Act (1990, 2001) in Singapore aims to control the sizes of religious communities. Malaysia intends to maintain Islamic dominance primarily constituted by Malays, and Christians are mainly Chinese and Indians converted from Buddhism and Hinduism..$^{15}$ In India, since the Bharatiya Janata Party, which advocates the Hindu nationalist ideology of Hindutva, won the election in 2014, anti-Christian violence has increased. Pentecostals are "disproportionately targeted" due to their "more assertive evangelism and willingness to demonize Indian culture and religions." Pentecostals are also targeted because of the "global flow of money and missionary methods" through the engine of globalization. ${ }^{16}$

12 They are Deloitte, Ernst and Young, KPMG, and PricewaterhouseCoopers.

13 Chong and Goh, "Asian Pentecostalism," 410.

14 James Hosack and Jason Morris, "Pentecostalism in Thailand and Vietnam," in Denise A. Austin, Jacqueline Grey, and Paul Lewis, eds., Asia Pacific Pentecostalism (Leiden: Brill, 2019), 161, 164-165.

15 William Kay, "The Dynamics of the Growth of Pentecostal Churches: Evidence from Key Asian Centres," Australian Pentecostal Studies, No. 15 (January 2013), https://aps-journal .com/index.php/APS/article/view/123, accessed July 28, 2020.

16 Chad M. Bauman, "Pentecostals and Interreligious Conflict in India: Proselytization, Marginalization and Anti-Christian Violence," PentecoStudies 16, no. 1 (2017): 8, 17. 


\subsection{Marketing and Hi-tech Equipment}

The resourceful megachurches vividly demonstrate the multifaceted nature of global Pentecostalism in the twenty-first century. Their gigantic buildings are always eye-catching to Christians and non-Christians. Simply by their existence in cities, they illustrate voicelessly what the prosperity gospel means. Megachurches have adopted "marketing strategies, technologies, and consumerist ethos to advance their brand of Christianity through rock concertlike worship sessions and televised sermons. ${ }^{17}$ Most of them can afford hi-tech video and audio equipment and musical instruments. Some of them can produce their own worship albums for sale in many countries. For example, Joshua Band was founded by the youth group of the BLCC in 1998. It first translated English praise-and-worship songs of Hillsong, Gateway Church, and Bethel Church into Chinese. Then they began to write their own songs in line with the Chinese context. ${ }^{18}$ Their albums have been sold in Chinese-language bookstores and churches in Asia.

\subsection{Good Life and Holistic Blessings}

Most of the megachurches provide counseling services through combining the charisms of healing and counseling techniques. For example, 611 opened a healing center to provide "outpatient" and "intensive" ministry soon after the church was planted. The counselors pray under the guidance of the Spirit to treat any emotional wounds, sin, idolatry, evil powers, or inherited family curses. ${ }^{19}$ Some also hold workshops on career planning to help members to seek their divine vocations. ${ }^{20}$ As Kong Hee taught his congregation in 2012, "Prosperity is not just about you getting rich but it's that you becoming successful to fulfil the purpose of God for your life. So here in City Harvest Church we don't back away from prosperity. We're not afraid of prosperity."21 These ministries aim to help members to claim holistic blessings, including material wealth and physical and psychological health promised by God. As Chong states, "The prosperity gospels need to be contextualized as the broader desire to claim the 'good life' as promised by God in the here and now. It dovetails with the belief that God desires followers to enjoy life and its earthly

\footnotetext{
17 Chong and Goh, "Asian Pentecostalism," 407-408.

18 https://www.joshua.com.tw/web/?menu=editor\&menu_id=34, accessed June 26, 2020.

19 Connie Au, "Pentecostal Spirituality: Beliefs, Ethos, Practice," in Frank C. Senn, ed., Protestant Spiritual Traditions, vol. 2 (Eugene, OR: Wipf and Stock, 2020), 151.

$20 \quad$ Chong and Goh, "Asian Pentecostalism," 408.

21 Chong, "Of Riches and Faith," 162.
} 
bounties to the fullest, including financial prosperity, good health and the fulfilling of individual potential." 22

\subsection{Easy Travel and Transnational Ministries}

Easy travel as one of the fruits of globalization facilitates the megachurches to spread their "successful" messages at international and regional revival conferences. These churches can also invite foreign celebrity pastors to speak, lead worship, and conduct healing services. This phenomenon demonstrates how megachurches clone each other's administrative structures, ministerial methodology, worship styles, and the interior design of worship space. As Chong claims, "This allows for a cross-fertilization of executive norms and practices thus ensuring that while local culture and histories anchor these megachurches, they are also relatively homogeneous in terms of administrative and organizational make-up." ${ }^{23}$

Most of these megachurches plant churches in other Asian countries and even in the West. For example, the City Harvest Church has developed forty-two affiliate churches. ${ }^{24}$ The transnational establishment of a particular Protestant megachurch or Catholic Charismatic group vividly demonstrates how "successful" a gospel entrepreneur can be, vis-à-vis the entrepreneurs of investment banks, which often claim to be global corporations serving local customers. The transnational ecclesial corporation is assisted by electronic banking systems to collect tithes, so that members can easily transmit their offerings from their accounts wherever and whenever they want to. ${ }^{25}$ The social medias also easily connects members of different "chapters" around the world without any cost.

\subsection{Comment}

Adopting Lanz and Oosterbaan's phrase, Kirby reckons Pentecostalism as an "entrepreneurial religion" since pentecostal congregations enact "entrepreneurial self-government" and construct a "radically free-market organizational structure" found in neoliberal organizations. ${ }^{26}$ Pentecostalism fully manifests the characteristics of industrial capitalism, which emphasizes "systematic pursuit of efficiency and the accumulation of capital through the rationalization and refinement of 'the technical means of production, transportation, communication, finance, and management.'” Kirby considers that Pentecostalism

\footnotetext{
22 Chong and Goh, "Asian Pentecostalism," 408.

23 Chong and Goh, "Asian Pentecostalism," 411.

24 City Harvest Church's website, https://thn.chc.org.sg/network/, accessed June 20, 2020.

25 Chong and Goh, "Asian Pentecostalism," 408.

26 Kirby, "Pentecostalism, Economics, Capitalism," 16.
} 
"is arguably positioned at the very forefront of neoliberalizing processes that are remaking the "rationalist telos of modernisation and development." ${ }^{27} \mathrm{He}$ rightly explains why megachurches appeal to the younger generation and the middle class, who are surprised to discover that the pursuit of success in their workplaces can also be found and encouraged in churches. ${ }^{28}$

Pentecostals may well be aware of the power of evil spirits and how they can oppress human beings, but as the "beneficiaries of the present economic order," 29 they may not notice the incarnations of avarice existing in economic structures and investment markets. The world learned the painful lesson of globalization in 2008 when the economic bubble created by the investment banks suddenly burst. Asian regions such as Hong Kong, where the third global financial hub is installed and follows the heartbeat of Wall Street, suffered badly. The burst dashed the dreams of millions of people who had aimed for quick and easy money by investing their life savings in certain products. Similarly, Asian Pentecostals are not unfamiliar with the burst of the dream for a good life woven by the prosperity gospel. They have seen their distinguished leaders adopt luxurious lifestyles and embezzle church funds for their family members' businesses, funds that were contributed by the members with a hope of God's blessings in return. ${ }^{30}$

27 Kirby, "Pentecostalism, Economics, Capitalism," 14-15.

28 William Kay's research on megachurches in Hong Kong, Singapore, and Malaysia discovers a strong positive correlation between church growth and pastoral teaching of success in workplaces. William Kay, "The Dynamics of the Growth of Pentecostal Churches."

29 Kirby, "Pentecostalism, Economics, Capitalism," 14, n. 16.

30 Yonggi Cho was found guilty of embezzlement in 2014 as he encouraged church officials to buy the stock of his son for four times more than the market value in 2002. He was fined \$4.6 million and was sentenced to three years of suspended imprisonment. Kong Hee was convicted of misappropriating \$24 million of church funds partly to finance his wife's career and lifestyle and $\$ 26$ million to "cover up the first amount to fool auditors and to conceal the unauthorised use of the money from the church's building fund." He served his sentence from April 21, 2017 to August 22, 2019. https://www.christianpost.com/news/ megachurch-pastor-david-yonggi-cho-convicted-of-embezzling-12m-says-suffering-taug ht-him-individuals-shouldnt-possess-anything.html; https:/www.channelnewsasia.com/ news/singapore/kong-hee-city-harvest-church-founder-released-prison-11829342, accessed June 27, 2020. 


\section{Pentecostalism in Less Free Asian Countries}

\subsection{Myanmar}

Myanmar was a British colony from 1824 until 1948 when the people gained independence. Local people and foreign missions enjoyed religious freedom until 1962, when the military regime led by General Ne Win usurped the political power of the democratic government. The military government suspended the constitution and launched a single party called Burma Socialist Program Party in 1974. In 1988, the military government abandoned their socialist system. In 2010, it conducted a general election and implemented democratic reforms such as releasing the then democratic leader Aung San Suu Kyi from house arrest, granting amnesties for more than two hundred political prisoners, and relaxing press censorship and rules against labor strikes.

During the military regime, the economy had declined, which resulted in countrywide poverty. ${ }^{31}$ It is one of the thirty-six least-developed countries of the World Trade Organization (WTO) and one of the forty-seven of the United Nations (UN) as of 2018. ${ }^{32}$ Despite the devastating economic situation, the military government forbade churches from running social and humanitarian institutions such as schools and hospitals and nationalized them all. ${ }^{33}$ As the government gave up its socialist system in 1988, churches began to engage in social services. Myo Chit, who was the general superintendent of Assemblies of God of Myanmar, launched children's programs and financial assistance for tuition fees. The church also opened orphanages, schools, agricultural and livestock breeding projects, and water transportation projects. ${ }^{34}$ By 2017, Myanmar had 150,00o Pentecostals and 1,200 congregations. The AG is the third largest denomination in Myanmar and is especially strong among ethnic minorities. ${ }^{35}$

31 Saw Tint Sann Oo, "Social Concern and the Assemblies of God in Myanmar," in Denise A. Austin, Jacqueline Grey, and Paul Lewis, eds., Asia Pacific Pentecostalism (Leiden: Brill, 2019), 181-182.

The list is reviewed every three years. The UN defines these countries as "low-income countries confronting severe structural impediments to sustainable development. They are highly vulnerable to economic and environmental shocks and have low levels of human assets." https://www.un.org/development/desa/dpad/least-developed-country-ca tegory.html, accessed June 28, 2020.

33 Oo, "Social Concern," 181-182.

34 Oo, "Social Concern," 183-184.

35 Oo, "Social Concern," 190. 


\subsection{Cambodia}

After gaining independence from France in 1953, Cambodia has suffered under various brutal and oppressive regimes. The two worst ones were communist: Khmer Rouge (1975-1978) and Vietnamese occupation (1978-1992). The former killed between one and two million people in just three years. The country began to stabilize in 1993 when Norodom Sihanouk was restored as King of Cambodia, but the power belonged to the government established under the United Nations Transitional Authority in Cambodia. Cambodian Christians regard 1993 as the year of the rebirth of churches. Since then they have enjoyed freedom of worship. ${ }^{36}$ However, the co-prime minister Hun Sen waged a coup d'état in 1997 to overpower the noncommunist parties in the government. Although Sen's government has had a bad record in human rights, the country has been relatively stable until now.

Despite this relatively stable political environment, Cambodia is still stricken with poverty. Like Myanmar, it is one of the thirty-six least-developed countries of the WTO and one of the forty-seven of the UN in 2018. Hence, foreign charitable and humanitarian works are welcomed and such missionary efforts seem to be more enduring than evangelical crusades. ${ }^{37}$ In September 1990, two American Assemblies of God (AG) missionaries, Randy and Carolyn Dorsey, were sent to Cambodia to establish two children's homes and one medical clinic and to teach English. ${ }^{38}$ Afterwards, AG missionaries from France, the Philippines, Australia, and Malaysia served the country. In 1999, AG missionaries launched the Cambodia Global Action as a pilot Community Health Education Programme in four villages in Kompong Speu Province. The programme served fifty-seven villages by 2003 and had more than ninety Cambodian staff by 2018. Foursquare Missions International started social welfare ministries aiming at healing and restoration, especially for children, through American missionaries Ted and Mak Sou Olbrich in 1998. ${ }^{39}$ The AG in Cambodia was officially founded in 1997 and Cambodia Bible Institute was established in 1994. By 2015, it had 69 churches, 91 organized churches, and 58 house

36 Darin Clements, Ken Huff and Nyotxay, "The Development of Pentecostalism in Cambodia and Laos," in Denise A. Austin, Jacqueline Grey, and Paul Lewis, eds., Asia Pacific Pentecostalism (Leiden: Brill, 2019), 131-132.

Mike Evans of the AG launched a crusade in Phnom Penh in 1994, but it was suspended since Evans was alleged to have directly attacked Buddhism and fled. Joyce Meyer Ministries attempted to hold a crusade in 2007 but was rejected by the government. Clements, Huff, and Nyotxay, "The Development," 134-135.

38 Clements, Huff and Nyotxay, "The Development," 135.

39 Clements, Huff and Nyotxay, "The Development," 142-143. 
churches and cell groups, with 69 recognized pastors and 183 leaders, 5,900 adults, and 7,400 children. ${ }^{40}$

On June 24, 2016, prime minister Hun Sen met with 2,500 Christians leaders for the first time. Despite enshrining Buddhism as the state religion, he promised religious freedom to Christians but reprimanded denominationalism, which might threaten national stability. With Islam being the second religion, he acclaimed Christianity as the "third" and "youngest religion." ${ }^{\text {11 }}$

\subsection{Vietnam}

On April 30, 1975, communist North Vietnam captured Saigon and unified Vietnam, which forcefully ended the separation between the northern socialist state called the Democratic Republic of Vietnam and the southern noncommunist Republic of Vietnam, which had existed since $1954 .{ }^{42}$ This date marks the beginning of the "dark decade" from 1975 to 1985 , during which thousands of Vietnamese fled to Malaysia, Indonesia, and Hong Kong, waiting to be accepted as refugees in Western countries. ${ }^{43}$ Many Christians were severely persecuted and were sentenced to long imprisonments. Pentecostals such as Vietnam Assemblies of God (VAOG) were no exception. In December 1986, reformers of the communist party implemented free-market reforms and allowed private ownership and foreign investments. These measures brought the country out of poverty and economic inefficiency. Vietnam was not among the UN's fortyseven least developed countries in 2018.

Since the reopening of the country, the government also permitted foreign humanitarian relief, and the Assemblies of God Division of Foreign Missions gained permission from the government to send missionaries to conduct relief work in 1991. Subsequently, AG missionaries from different countries, including the US, Australia, France, and New Zealand, came to provide medical equipment, rice, education, water purification techniques, rescue for the victims of human trafficking, and basic housing in the northern, central, and southern parts of Vietnam. ${ }^{44}$ While missionaries endeavored to provide humanitarian support in the 199os, local evangelicals in the twenty-first century, who as ethnic minorities have suffered from social marginalization and oppression, envi-

\footnotetext{
40 Clements, Huff and Nyotxay, "The Development," 136, 138.

41 Clements, Huff and Nyotxay, "The Development," 145-146.

42 Vince Le, Vietnamese Evangelicals and Pentecostalism: The Politics of Divine Intervention (Leiden: Brill, 2018), 36.

43 Hosack and Morris, "Pentecostalism," 162.

44 Hosack and Morris, "Pentecostalism," 168.
} 
sion the realization of social justice in three dimensions: love, human rights, and divine deliverance. ${ }^{45}$

In 1989, VAOG held a general council meeting where Rev Tran Dinh Paul Ai was elected as general superintendent. In 2009, VAOG was allowed to establish a resident Bible school in Ho Chi Minh City. In 2010, it was officially recognized as a religious entity. By 2016 there were about 400,00o Pentecostals in Vietnam of which three quarters belong to ethnic minorities. ${ }^{46}$

\subsection{China}

Since 1949, when the communists seized political power, they launched political movements unceasingly to purge anyone whom they conceived of as dissidents. The anti-right movement oppressed intellectuals, businesspeople, Nationalist veterans, religious members, and landlords. The Three-Self Patriotic Movement specifically targeted the Catholic Church and Protestant churches. Ultimately the Cultural Revolution brought about a wholesale persecution against the alleged dissidents within the communist party, families, schools, factories, and any other sectors in the society. This political chaos was halted by the death of Mao Zedong in 1976 . The country began to reopen to the outside world since the governance of the reformers led by Deng Xiaoping in 1978. Some businessmen especially from Hong Kong were invited to open factories, and Christian leaders were allowed to visit. The reformers incorporated capitalist elements in their economic reform, which paved the way for China to become a member of the wTO in 20o1. This membership has given China the opportunity to engage in global trade, through which it has brought millions of people out of poverty and created thousands of billionaires and global entrepreneurs.

Before the outbreak of the coronavirus pandemic, Chinese Pentecostals in Singapore, Korea, Hong Kong, and Taiwan and Western missionaries seized the opportunity opened by globalization to serve the Three-Self and house churches. They traveled to major cities to conduct worship and gave biblical and pastoral training to the local Christians. Pastoral training often includes the teachings of Spirit baptism and the practice of spiritual gifts. One of the pioneers is Dennis Balcombe, who established Revival Church in Hong Kong and has aimed to spread the revival message to the Chinese Christians since the 1970s. The Singaporean churches regularly sent their training to China, and Korean churches provide financial resources and missionaries to serve the

45 Le, Vietnamese Evangelicals and Pentecostalism, 2, 35.

46 Hosack and Morris, "Pentecostalism," 166-168. 
Korean Chinese in urban and suburban areas. In the early 20oos, the unprecedented degree of religious freedom gave birth to numerous house churches' buildings. Coastal cities such as Wenzhou, where Christianity flourished, was even called "China's Jerusalem." ${ }^{77}$ The decades of wounds caused by the persecution of the Three-Self churches against the house churches were gradually healed. Some of the Three-Self churches, which were formerly founded by local Pentecostals and foreign missionaries of the AG, Pentecostal Assemblies of Canada, Pentecostal Holiness Church, and the Pentecostal Mission of Hong Kong before 1949, have not forgotten their pentecostal roots. They maintain the practices of speaking in tongues and healing during worship, though not in public.

However, the pendulum has swung back to the prereform period since 2012, when Xi Jinping became the general secretary of the Communist Party. The metaphor of "China's Jerusalem" is still valid but needs an added remark: "in the time of Caesar Nero." Over two thousand crosses and church buildings of both official Three-Self and unofficial house churches have been smashed with cranes and excavators in the name of violation of architectural regulations. Children and teenagers under eighteen years old are not allowed to attend churches. Online communication between church members has been constantly spied on by security authorities. During the coronavirus shutdown, in some areas even online services were forbidden. To deter "foreign infiltration," certain authorities collaborated to crack down on missionary activities. In 2018, the Chinese religious affairs department enforced a "special action plan to investigate and prosecute Korean Christian infiltration according to the law" through the "township and community authorities, police and cyberspace affairs authorities." Voice of the Martyrs Korea reported that between 2016 and 2018, one thousand Korean missionaries were either expelled from China or their visa applications rejected ${ }^{48}$ Human rights groups around the world have protested against all sorts of oppression, but Western governments seem to be reluctant to react, allegedly due to their interest in trade deals with China.

47 Nanlai Cao, Constructing China's Jerusalem: Christians, Power, and Place in Contemporary Wenzhou (Redwood City, CA: Stanford University Press, 2010); “The Undercurrent Coming to the Surface: Pentecostal Strategies, Entrepreneurship, and the Nation State in the Chinese World," PentecoStudies, 19, no. 1 (2020): 8-35.

48 Mimi Lau, "South Korean Missionaries Fearful as Crackdown on 'Infiltration' in China Gathers Pace," South China Morning Post, June 1, 2018, https://www.scmp.com/news/chin a/policies-politics/article/2150057/south-korean-missionaries-fearful-crackdown, accessed June 19, 2020. 


\subsection{Comment}

Totalitarian regimes launched brutal political movements that claimed millions of lives to strengthen their power, but these movements and the "white terror" that followed always caused stagnant economies and social instability. These consequences eventually push these regimes to open their markets, which means being involved in globalization. Pentecostals cannot openly evangelize the locals and practice spiritual gifts, but they are allowed to launch charitable programs. Pentecostalism in China flourished in the 2ooos with the effort of foreign and local Pentecostals, but since the rule of law is not enacted there, the destiny of both the Three-Self and houses churches depends on the mercy of the authorities of villages, cities, provinces, and the central government.

On the whole, globalization may improve the economic condition and social instability, but the wealth that it brings about is often possessed only by a tiny portion of people, including politicians, local and foreign investors, and the privileged elite of the country. In other words, it widens the discrepancy between the rich and the poor. The above examples show that globalization cannot lead to substantial political and legal reforms of totalitarian governments. The well-meaning assumption made by Westerners that the creation of a middle class may facilitate the birth of genuine democracy, freedom, and rule of law has proved to be invalid. Genuine democracy does not even happen in Singapore.

\section{$5 \quad$ Mission and Migration}

\subsection{Africans to China}

Since the late 199os, entrepreneurs and businesspeople from both the developed and developing countries rushed into China's market. African, Middle Eastern, and South Asian traders have been actively doing business in Guangzhou, Yiwu, and Hong Kong. Particularly, China and Africa have developed close commercial ties. The growth of trade between China and Africa increased by "an average of 28 per cent year between 1999 and 2009 in terms of monetary value adjusted for inflation." The Forum on China-Africa Cooperation has been conducted every three years since 2000. ${ }^{49}$

49 Heidi Østbø Haugen, "Chinese Exports to Africa: Competition, Complementarity and Cooperation between Micro-Level Actors," Forum for Development Studies 38, no. 2 (June 2011): 16o. 
Besides the formal and official trade, Africans also engage in informal and small-scale commercial activities in China. Some of the products are "knockoff goods, whose logos have been appropriated from the brands of high-end globalization." They take these products back to their home countries by both legal and illegal means for sale by street vendors. Gordon Matthew, an anthropologist of the Chinese University of Hong Kong, reckons that this kind of trade creates "low-end globalization" or "globalization from below," in comparison to the "high-end globalization" that is run by large corporations working within the law. He argues that low-end globalization is the only form of globalization that most of the developing countries experience and China plays a vital role in mobilizing this grassroots globalization among these countries. ${ }^{50}$

Both formal and informal trade enhance frequent Sino-African commercial and cultural exchanges. Some Africans have been issued resident permits in China. Some marry Chinese women and do the trading between China and Africa as a family. Some enrol in university programs to learn the Chinese language and business. Some itinerant traders travel between China and Africa six to twelve times a year, usually on tourist visas. Some whose thirty-day visa has expired take the risk of police arrest and repatriation..$^{51}$ In Guangzhou, Sanyuanli is almost an African area in which Chinese faces are rare. They are mainly Igbo Christians from the south of Nigeria, while Yuexiu District is popular with Muslims, francophone Africans, and Middle Easterners. ${ }^{52}$

African Pentecostals bear the same risk as the Chinese Christians of being arrested by the police if they attend an unregistered church. Heidi Østbø Haugen, a Norwegian anthropologist, spent a year between 2012 and 2013 to study the African pentecostal migrants in Guangzhou. She conducted her fieldwork in The Tower of Salvation World Mission. This African house church meets in hotels or a rented property, and only Africans are allowed to attend since the security bureau enforces stricter measures on Chinese than on foreigners regarding attending nonregistered religious societies. Their sermons are conducted in English, French, Portuguese, and African languages. ${ }^{53}$ Contrasting with the African habit of socializing after services in free countries, these Pentecostals leave the church immediately in small groups to avoid police attention.

50 Gordon Mathews and Yang Yang, "How Africans Pursue Low-End Globalization in Hong Kong and Mainland China," Journal of Current Chinese Affairs 41, no. 2 (2012): 96-98.

$5^{1}$ Haugen, "Chinese Exports to Africa," 168; "African Pentecostal Migrants in China: Marginalisation and the Alternative Geography of a Mission Theology," African Studies Review 56, no. 1 (April 2013): 9 o.

52 Mathews and Yang, "How Africans Pursue Low-End Globalization," 110.

53 Haugen, "African Pentecostal Migrants," 84, 96. 
To survive in this critical and dangerous situation, African pastors have learned to liaise with the Public Security Bureau. ${ }^{54}$

Haugen discovered a strong orientation to the prosperity gospel related to the oppressive context in the pastor's preaching. For example, he prophesied to his members that they would be shielded from police harassment, especially those who had an expired visa; they would be issued a visa for Europe; his members would not be inflicted with SARs in 2003; there would be 250 multibillionaires in his churches; and their trading would be successful in China. Although church buildings are the visible sign of prosperity in their African home countries, especially Nigeria, these African Pentecostals in China regrettably have to stay invisible for their safety. ${ }^{55}$

Both Haugen and Kirby discovered that Africans in China and Hong Kong consider themselves fitted for the mission there, "having passed through persecution, slavery, long economic suffering, rejection, and exploitation." ${ }^{56}$ In this regard they see themselves as superior to the White people and criticize the Europeans for abandoning the truth of Christianity and embracing social liberalism. ${ }^{57}$ Nevertheless, African Pentecostals in mainland China cannot possibly evangelize the Chinese due to the language barrier, their perception of the Chinese as atheists and ungodly people, the ban on public evangelism, Chinese racial discrimination against Africans, and accusations against their alleged illegal conduct. Consequently, their primary goal is solely to pastor African migrants. ${ }^{58}$

Although Hong Kong is only 129 kilometers away from Guangzhou, the political situation that African pentecostal migrants experienced was relatively different. ${ }^{59}$ Kirby interviewed four African pentecostal pastors, mainly Nigerians, during the Umbrella Movement in 2014. As an international city, Africans in Hong Kong are rarely discriminated against by race and certainly not generalized as criminals. They are free to evangelize anyone and found churches. African-initiated churches not only serve fellow migrants who may be traders like those in Guangzhou but also female domestic helpers from Indonesia and the Philippines. They also welcome Hongkongers and students from mainland

\footnotetext{
54 Haugen, "African Pentecostal Migrants," 90, 92.

55 Haugen, "African Pentecostal Migrants," 90-91, 95.

56 Kirby, "Occupying the Global City," 66.

57 Haugen, "African Pentecostal Migrants," 93.

$5^{8}$ Haugen, "African Pentecostal Migrants," 94, 96-97.

59 On July 1, 2020, the national security law was imposed by Beijing on Hong Kong, which means that the freedom guaranteed by the Basic Law for fifty years (1997-2047) was prematurely ended.
} 
China. ${ }^{60}$ In 2019, the Ghanaian Church of Pentecost also set up a branch in Hong Kong to serve the same groups of migrants. Kirby discovered that African migrant networks generally consider Hong Kong as the "third-best" destination as a global city, after the US and UK. ${ }^{61}$

\subsection{Filipinas to the World}

For the people of the developing countries, working in a developed country is a chance to get out of poverty. Filipina workers are a vivid example of this phenomenon. Due to the decades-long economic recession and corruption in their country, Filipinas cannot find work apart from that of domestic helpers, nurses, and caregivers for elderly homes in Hong Kong, Taiwan, the Middle East, and Western countries. Since most Filipinas are Christians, they join the local English services or form their own worship groups as long as the local government accepts Christianity. These Filipina migrant workers unconsciously create global networks of the Catholic Charismatic renewal and pentecostal churches. Jesus Is Lord Pentecostal Church has developed eighty-five branches in the Philippines and thirty-seven overseas chapters. ${ }^{62}$ The two largest Filipino/a Catholic Charismatic groups have planted numerous chapters both in the Philippines and across the world. El Shaddai has 104 chapters. ${ }^{63}$ The Loved Flock has about one million members and eighty chapters in the Philippines. Its communities have spread to the US, Canada, Italy, Germany, Austria, Spain, Korea, Hong Kong, and Taiwan. ${ }^{64}$

Those Filipino/as pentecostal and charismatic migrants who are economically unprivileged take the tide of globalization to work in many parts of the world, hoping to give themselves and their children better economic conditions. They contribute to the receiving countries not only with their labor but also with their Christian faith with which to redevelop and revive churches in the Global North, where Christianity is declining. If this extraordinary and widespread phenomenon is attributed to the work of the Holy Spirit, then the contemporary waves of migration in the twenty-first century, bringing the

6o Benjamin Kirby, "Occupying the Global City: Spatial Politics and Spiritual Warfare among African Pentecostals in Hong Kong," in David Garbin and Anna Strhan, eds., Religion and the Global City (London: Bloomsbury, 2017), 67.

$61 \quad$ Kirby, "Occupying the Global City," 68.

62 https://www.google.com/maps/d/viewer?mid=1z3lvc9PMc5-wisk-JqpqpLJxiYwDzXbn\&ll $=12.57800665641361 \% 2 \mathrm{C11} 8.45163012500007 \& \mathrm{z}=5$, accessed June 25, 2020 .

63 https://www.google.com/maps/d/viewer?msa=o\&mid=1WymECFmaEG7SoMG4zRZxggy R3hw\&ll=-3.81666561775622e-14\%2C141.2489o849999997\& z=1, accessed June 25, 2020.

64 Connie Au, "The Migrant Spirit: A Study of the Filipina Catholic Charismatics of the Loved Flock in Hong Kong," Asia Journal of Theology 32, no. 2 (October 2018): 128. 
oppressed from the Global South to the Global North due to political, economic, and other circumstances, which scholars identify as "the age of migration," has become a humanitarian movement of the Holy Spirit. ${ }^{65}$

\section{Conclusion: The Future of Globalization and Asian Pentecostalism under Covid-19}

According to the World Health Organization, as of 18 October, 2020, there have been $39,596,858$ confirmed cases and the coronavirus has claimed 1,107,374 lives. ${ }^{66}$ It has spread to the developed, developing, and least developed, freer and less free countries. It will not end in the near future until a vaccine is made to be widely and affordably available. The coronavirus exposes the delicate and vulnerable network created by globalization through easy travel. It swiftly and equally infects all human beings regardless of political, economic, racial, social, educational, and gender status. The fact that governments were reluctant to close their borders reveals the priority given to their economy and trade deals over human lives. Ironically, the longer they took to close the borders, the more they lost economically, the more their citizens died, and the least support they got from the public. So far, one of the benefits that the coronavirus brings about is the recovery of a clear sky and fresh air.

Political and economic commentators have concluded that this coronavirus brought the end of globalization or at least of the conditions with which we have been familiar. The Economist advises, "Wave goodbye to the greatest era of globalisation - and worry about what is going to take its place."67 Time states, "Just as COVID-19 is a virus with global qualities, globalization is itself viral. But all viruses evolve, and globalization is no different." ${ }^{\prime 68}$ Foreign Policy concludes, "The coronavirus pandemic may mark the endpoint of the post-Cold War era. The enchantment with ever-greater international integration is gone." 69

\footnotetext{
$65 \mathrm{Au}$, "The Migrant Spirit," 138.

66 https://covidig.who.int, accessed on October 18, 2020.

67 "Has Covid-19 Killed Globalisation? The Flow of People, Trade and Capital Will Be Slowed," The Economist (May 14, 2020), https://www.economist.com/leaders/2020/05/14/has-covid -19-killed-globalisation, accessed June 17, 2020.

68 Arjun Appadurai, “Coronavirus Won't Kill Globalization. But It Will Look Different After the Pandemic," Times (May 19, 2020), https://time.com/5838751/globalization-coronaviru s/, accessed June 17, 2020.

69 Richard Fontaine, "Globalization Will Look Very Different After the Coronavirus Pandemic," Foreign Policy (April 17, 2020), https://foreignpolicy.com/2020/04/17/globalization -trade-war-after-coronavirus-pandemic/, accessed June 17, 2020.
} 
Having experienced SARS in 2003, Asians are not unfamiliar with regional epidemics. After seventeen years, the horror of sARs still remains in the living memory of most Asians. We may be more alert and stock up on sanitizers and facial masks to protect ourselves from Covid-19; however, this virus has proven to be more contagious than SARS. In Singapore, infected cases were found in Grace Assembly of God and Life Church and Missions Singapore. ${ }^{70}$ These incidents have caused worldwide churches to launch online services, which has fundamentally challenged a core element of pentecostal spirituality, namely, physical corporate worship. If worship is the fountain that bursts out of the celebration of victory, the exercises of charisms, the preparation for healing, and the sense and reality of divine-human intimacy, then this pandemic reminds Pentecostals how much they need to cherish the time of fellow worshipers' physical presence.

Online services may maintain a certain spirit of worship but do not have the same level of offering. Due to the shutdown, many people have lost their jobs or only work part time. The coronavirus has hit the global economy badly, especially the working class in Asia. Unless members of churches faithfully pay their offerings online, their churches suffer financially. Megachurches may have been hurt significantly. Mark Mulder and Gerardo Martí discusses how megachurches sustain themselves financially: "The need for fresh flows of capital means a constant influx of people committed to the congregation, which, history suggests, depends on the force of communal excitement and face-toface experiences." They also warn the megachurches of unexpected incidents: "When contingent events interrupt the rhythms and habits of congregational life, the consequences can be catastrophic."71

Unfortunately, the coronavirus has caused a worldwide shutdown and many airlines suffer from the huge loss of income. Missionary activities are also suspended. Many Filipina/os cannot travel to another country to work or have to extend the contract with the same employers. If Pentecostalism has been a global religion through its missionary ferment and network in the early twentieth century, then this pandemic is probably another contingency similar to that which caused the suspension of the global spread of Pentecostalism during the two world wars.

70 Xinghui Kok, "Coronavirus Spurs Singapore and Hong Kong Christians to See Crisis as Test of Faith and Unity," https://www.scmp.com/week-asia/health-environment/article/ 3051932/coronavirus-spurs-singapore-and-hong-kong-christians, accessed June 30, 2020.

71 Mark Mulder and Gerardo Martí, "Megachurches May Be Particularly Threatened by covid-19 Closures," https://religionnews.com/2020/o4/10/megachurches-can-be-particu larly-vulnerable-to-covid-19/, accessed June 18, 2020. 
The coronavirus seems to remind the world of the golden calf of avarice that it has been earnestly worshiping in the tide of globalization. It has been lured to absorb more wealth for oneself and one's country at the expense of the universal values of democracy, freedom, human rights, and the dignity of the entire creation. This pandemic leads the world to nowhere but profound confusion and fear. Nobody and no government can see the future and make any solid plans. Pentecostals are not immune from this turmoil, but they have inherited faith in the Holy Spirit, who reminds human beings of their sins and sanctifies their spirits to prepare them for his healing and renewal, so that the old world of sickness, injustice, and greed can be restored to a world of health, justice, and generosity, to be inherited by the next generation. As the senior pastor of Faith Community Baptist Church, one of the "Big Four" churches in Singapore, says, "God is not the cause of evil, but I believe he is using this Covid-19 situation to prepare the church for a new season." 72

72 Xinghui Kok, "Coronavirus Spurs Singapore and Hong Kong Christians." 